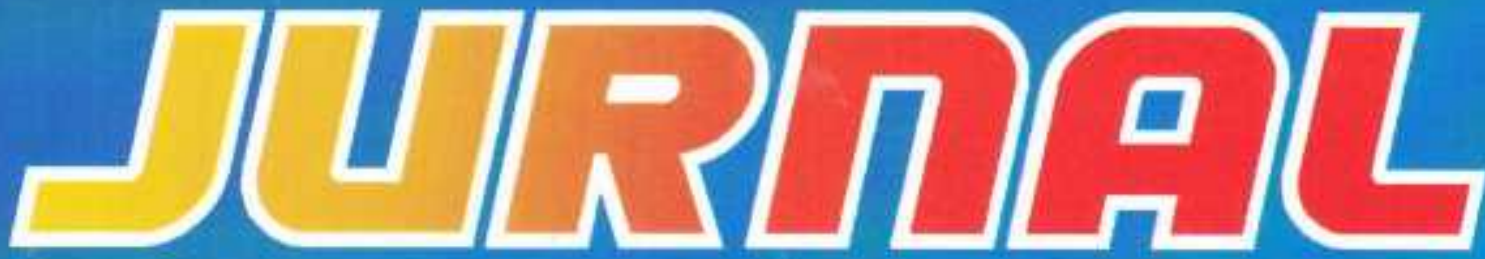

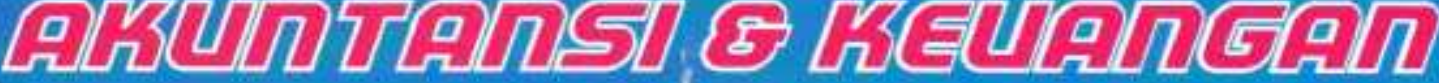

Volume 6, No. 1, Maret 2015

ISSN: $2087-2054$

Pengaruh Peran Acoount Representative Terhadap Tingkat Kepatuhan Wajib Pajak (Studi kasus pada KPP Pratama di Kota Bandar Lampung)

\section{Angrita Denziana \& Handi Sutanto}

Pengaruh Biaya Iklan Dan Biaya Penjualan Personal Terhadap Nilai Penjualan Pada PT Telekomunikasi Indonesia, Tbk.

\section{Chairul Anwar \& Rinna}

Relationship Executives Rewards With Financial Performance On Corporate Banking In Indonesia

\section{Haninun \& Putri Cagora Nisa}

Analisis Penerapan Metode Pengakuan Pendapatan Terhadap Laba Perusahaan Pada Pt. Coca Cola Distribusi Indonesia (Cabang Tanjung Karang)

\section{Herry Goenawan Soedarsa \& Surya Pandelima}

Pengaruh Tingkat Suku Bunga Simpanan Terhadap Jumlah Deposito Pada Pt. Bank Rakyat Indonesia (Persero) Tbk. Cabang Liwa

\section{Indrayenti \& Susanti}

Pengaruh Motivasi Terhadap Minat Mahasiswa Akuntansi Untuk Mengikuti Pendidikan Profesi Akuntansi (PPAK) Di Provinsi Lampung

\section{Rosmiaty Tarmizi \& Julia Restuti}

Pengaruh Kinerja Hutang Terhadap Nilai Perusahaan Pada Perusahaan Pertambangan Batubara Yang Terdaftar Di Bei Periode 2010-2013

\section{Khairudin \& Rico Tanto}

Pengaruh Profitabilitas, Ukuran Perusahaan, Debt To Equity Terhadap Ketepatan Waktu Penyampaian Laporan Keuangan (Studi Pada Perusahaan Asuransi Yang Terdaftar Di BEI)

\section{Riswan \& Tri Lestari Saputri}

Pengaruh Manajemen Laba Terhadap Kinerja Keuangan Pada Perusahaam Manufaktur Tahun 2011-2012

\section{Aminah \& Lidya Natasia Gunakan}




\section{Dewan Pembina}

Dr. Ir. M. Yusuf S. Barusman, M.B.A

Dr. Andala Rama Putra Barusman, S.E., M.A.Ec.

\section{Penanggung Jawab}

Dra. Rosmiaty Tarmizi, M.M.Akt. C.A

\section{Pimpinan Redaksi}

Dr. Angrita Denziana, S.E., M.M, Ak. C.A

\section{Sekretaris Redaksi}

Aminah, S.E., M.S.Ak

Khairudin, S.E., M.S.Ak

\section{Penyuting Ahli}

Prof. Dr. Jogiyanto Hartono, M.B.A. ( Universitas Gadjah Mada)

Tina Miniawati, S.E., M.B.A. (Universitas Trisakti)

Dr. Khomsiyah, S.E., M.M. (Universitas Trisakti)

Dr. Lindrianasari, S.E., M.Si.Akt. (Universitas Lampung)

Sujoko Efferin, Mcom (Hons), MA(Econ), Ph.D. (Universitas Surabaya)

\section{Penerbit}

Universitas Bandar Lampung

Fakultas Ekonomi dan Bisnis Program Studi Akuntansi

SENARAI-Jurnal Akuntansi \& Keuangan Terbit 2 kali setahun pada bulan Maret \&

September

Artikel yang dimuat berupa hasil riset Empiris dan telaah teoritis konsepsual yang kritis dalam kajian bidang akuntansi, auditing, perpajakan, dan keuangan.

\section{Alamat Redaksi}

Gedung G- Program Studi Akuntansi Fakultas Ekonomi dan Bisnis Universitas Bandar Lampung

Kampus A Jalan Z.A Pagar Alam No. 26 Labuan Ratu Bandar Lampung 35142

Telp: (0721) 701979, Fax: (0721) 701467, Email: Prodi.akuntansi@ubl.ac.id 


\section{JURNAL \\ AKUNTANSI \& KEUANGAN}

Volume 6, No. 1, Maret 2015

ISSN: 2087-2054

Pengaruh Peran Acoount Representative Terhadap Tingkat Kepatuhan Wajib Pajak

(Studi Kasus pada KPP Pratama di Kota Bandar Lampung)

Angrita Denziana \& Handi Sutanto

Pengaruh Biaya Iklan dan Biaya Penjualan Personal Terhadap Nilai Penjualan Pada PT

Telekomunikasi Indonesia, Tbk.

\section{Chairul Anwar \& Rinna}

Relationship Executives Rewards With Financial Performance On Corporate Banking In Indonesia

\section{Haninun \& Putri Cagora Nisa}

Analisis Penerapan Metode Pengakuan Pendapatan Terhadap Laba Perusahaan Pada PT. Coca Cola Distribusi Indonesia (Cabang Tanjung Karang)

Herry Goenawan Soedarsa \& Surya Pandelima

Pengaruh Tingkat Suku Bunga Simpanan Terhadap Jumlah Deposito Pada PT. Bank Rakyat Indonesia (Persero) Tbk. Cabang Liwa

Indrayenti \& Susanti

Pengaruh Motivasi Terhadap Minat Mahasiswa Akuntansi Untuk Mengikuti Pendidikan Profesi Akuntansi (PPAK) Di Provinsi Lampung

\section{Rosmiaty Tarmizi \& Julia Restuti}

Pengaruh Kinerja Hutang Terhadap Nilai Perusahaan Pada Perusahaan Pertambangan Batubara Yang Terdaftar Di BEI Periode 2010-2013

\section{Khairudin \& Rico Tanto}

Pengaruh Profitabilitas, Ukuran Perusahaan, Debt To Equity Terhadap Ketepatan Waktu Penyampaian Laporan Keuangan (Studi Pada Perusahaan Asuransi Yang Terdaftar Di BEI) Riswan \& Tri Lestari Saputri

Pengaruh Manajemen Laba Terhadap Kinerja Keuangan Pada Perusahaam Manufaktur Tahun 2011-2012

\section{Aminah \& Lidya Natasia Gunakan}




\section{JURNAL \\ AKUNTANSI \& KEUANGAN}

Volume 6, No. 1, Maret 2015

ISSN: 2087-2054

Daftar Isi

Halaman

$1-22$

Pengaruh Peran Acoount Representative Terhadap Tingkat Kepatuhan

Wajib Pajak (Studi kasus pada KPP Pratama di Kota Bandar Lampung)

Angrita Denziana \& Handi Sutanto

Pengaruh Biaya Iklan Dan Biaya Penjualan Personal Terhadap Nilai

Penjualan Pada PT Telekomunikasi Indonesia, Tbk.

Chairul Anwar \& Rinna

Relationship Executives Rewards With Financial Performance On

Corporate Banking In Indonesia

Haninun \& Putri Cagora Nisa

Analisis Penerapan Metode Pengakuan Pendapatan Terhadap Laba

Perusahaan Pada PT. Coca Cola Distribusi Indonesia (Cabang Tanjung

Karang)

Herry Goenawan Soedarsa \& Surya Pandelima

Pengaruh Tingkat Suku Bunga Simpanan Terhadap Jumlah Deposito Pada

PT. Bank Rakyat Indonesia (Persero) Tbk. Cabang Liwa

Indrayenti \& Susanti

Pengaruh Motivasi Terhadap Minat Mahasiswa Akuntansi Untuk

Mengikuti Pendidikan Profesi Akuntansi (PPAK) Di Provinsi Lampung

Rosmiaty Tarmizi \& Julia Restuti

Pengaruh Kinerja Hutang Terhadap Nilai Perusahaan Pada Perusahaan

Pertambangan Batubara Yang Terdaftar Di BEI Periode 2010-2013

\section{Khairudin \& Rico Tanto}

Pengaruh Profitabilitas, Ukuran Perusahaan, Debt To Equity Terhadap

Ketepatan Waktu Penyampaian Laporan Keuangan (Studi Pada Perusahaan Asuransi Yang Terdaftar Di BEI)

Riswan \& Tri Lestari Saputri

Pengaruh Manajemen Laba Terhadap Kinerja Keuangan Pada Perusahaam Manufaktur Tahun 2011-2012

Aminah \& Lidya Natasia Gunakan 


\section{JURNAL AKUNTANSI \& KEUANGAN}

Volume 6, No. 1, Maret 2015

ISSN: $2087-2054$

\section{Informasi Kebijakan dan Selingkung Berkala}

\section{Kebijakan editorial}

JURNAL Akuntansi \& Keuangan adalah sebuah berkala yang dipublikasikan oleh Universitas Bandar Lampung, yang bertujuan untuk menjadi wadah kreatifitas para akademisi, profesional, peneliti, dan mahasiswa di bidang Akuntansi dan Keuangan termasuk juga bidang Auditing, Sistem Informasi Akuntansi, Tata kelola Perusahaan, Perpajakan, Akuntansi Internasional, Akuntansi Managemen, Akuntansi Keperilakuaan, Pasar Modal dan lain sebagainya. Topik yang semakin meluas di bidang kajian riset Akuntansi diakomodir publikasinya di dalam berkala ini.

Paper yang akan dipublikasikan di dalam berkala JURNAL Akuntansi \& Keuangan harus ditulis di dalam bahasa Indonesia yang baik dan sesuai dengan EYD. Semua instrumen yang digunakan untuk memperoleh data penelitian harus dimasukkan di dalam lampiran paper penelitian, paling tidak, penulis bersedia memberikan klarifikasi atas instrumen yang digunakan saat ada permintaan dari peneliti lainnya.

\section{Sekretariat Editor Berkala}

Gedung F - Fakultas Ekonomi Universitas Bandar Lampung

Fakultas Ekonomi Program Studi Akuntansi

Kampus A Jalan Z.A. Pagar Alam No. 26 Labuhan Ratu Bandar Lampung 35142

$$
\text { Telp.: (0721) 701979, Fax.: (0721) 701467, Email: }
$$

\section{Petunjuk penulisan}

Artikel yang dikirim ke JURNAL Akuntansi \& Keuangan harus mengikuti petunjuk seperti berikut:

1. Naskah merupakan naskah asli yang belum pernah diterbitkan atau sedang dilakukan penilaian pada berkala lain. Naskah ditulis dalam bahasa Indonesia dengan jarak 1 spasi, sepanjang 20-30 halaman kertas A4 dengan tipe huruf Times New Roman.. Naskah dikirim atau diserahkan ke sekretariat JURNAL Akuntansi \& Keuangan rangkap satu disertai disket berikut dengan biodata penulis dan alamat lengkap (kantor dan rumah) pada lembaran yang terpisah dari halaman pertama artikel.

2. Judul naskah dapat ditulis dengan menggambarkan isi pokok tulisan, dan atau ditulis secara ringkas, jelas, dan menarik. 
3. Nama Penulis disertai catatan kaki tentang profesi dan lembaga tempat penulis bekerja dalam naskah yang telah diterima untuk diterbutkan.

4. Abstrak ketik satu spasi, tidak lebih dari 250 kata dalam bahasa Inggris. Abstrak memuat tujuan penelitian, isu, permasalahan, sampel dan metode penelitian, serta hasil dan simpulan (jika memungkinan).

5. Pendahuluan beriksikan uraian tentang latar belakang masalah, ruang lingkup penelitian, dan telaah pustaka yang terkait dengan permasalahan yang dikaji, serta rumusan hipotesis (jika ada). Uraian pendahuluan maksimum $10 \%$ total halaman.

6. Untuk penelitian kuantitatif,

a. Telaah Literatur dan Pengembangan Hipotesis memuat paling tidak satu buah teori yang menjadi dasar pemikiran penelitian. Hipotesis dikembangkan menggunakan asumsi dasar teori dan hasil penelitian sebelumnya. Telah literatur maksimum $40 \%$ total halaman.

b. Metodologi Penelitian meliputi uraian yang rinci tentang bahan yang digunakan, metoda yang dipilih, teknik, dan cakupan penelitian. Uraian bahan dan metoda maksimum $20 \%$ total halaman.

7. Untuk penelitian kualitatif menyesuaikan dengan metodologi kualitatif.

8. Hasil dan Pembahasan merupakan uraian obyektif dari-hasil penelitian dan pembahasan dilakukan untuk memperkaya makna hasil penelitian. Uraian hasil dan pembahasan minimum $25 \%$ total halaman.

9. Simpulan yang merupakan rumusan dari hasil-hasil penelitian. Harus ada sajian dalam satu kalimat inti yang menjadi simpulan utama. Simpulan maksimum 10\% dari keseluruhan lembar artikel.

10. Referensi (Daftar Pustaka) ditulis berurutan berdasarkan alphabetical, disusun menggunakan suku kata terakhir dari nama penulisnya, atau institusi jika dikeluarkan oleh organisasi.

a. Buku: nama penulis, tahun penerbitan, judul lengkap buku, penyunting (jika ada), nama penerbit, dan kota penerbitan.

b. Artikel dalam buku: nama penulis, tahun penerbitan, judul artikel/tulisan, judul buku, nama penyunting, kota penerbitan, nama penerbit, dan halaman.

c. Terbitan berkala: nama penulis, tahun penerbitan, judul tulisan, judul terbitan (bila disingkat, sebaiknya menggunakan singkatan yang baku), volume, nomor, dan halaman.

d. Artikel dalam internet: nama penulis, judul, dan situsnya.

e. Tabel diberi nomor dan judul dilengkapi dengan sumber data yang ditulis dibawah badan tabel, diikuti tempat dan waktu pengambilan data.

f. Ilustrasi dapat berupa gambar, grafik, diagram, peta, dan foto diberi nomor dan judul.

11. Setiap referensi yang digunakan di dalam naskah artikel menggunakan petunjuk yang dirujuk pada The Indonesian Journal of Accounting Research, sebagai berikut:

A. Kutipan dalam tubuh naskah paper harus disesuaikan dengan contoh berikut:

I. Satu sumber kutipan dengan satu penulis (Brownell, 1981).

II. Satu sumber kutipan dengan dua penulis (Frucot dan Shearon, 1991).

III. Satu sumber kutipan dengan lebih dari satu penulis (Hotstede et al., 1990).

IV. Dua sumber kutipan dengan penulis yang berbeda (Dunk, 1990; Mia, 1988).

V. Dua sumber kutipan dengan satu penulis (Brownell, 1981, 1983).

VI. Dua sumber kutipan dengan satu penulis diterbitkan pada tahun yang sama (Brownell, 1982a, 1982b). 
VII. Sumber kutipan dari lembaga harus dinyatakan dengan menggunakan akronim institusi (FASB, 1994)

B. Setiap artikel harus menulis referensi menggunakan panduan berikut:

I. Referensi harus tercantum dalam urutan abjad dari nama belakang penulis atau nama lembaga.

II. Referensi harus dinyatakan dengan urutan sebagai berikut: penulis (s) nama, tahun publikasi, judul kertas atau buku teks, nama jurnal atau penerbit dan nomor halaman. Contoh:

a) Amerika Akuntansi Association, Komite Konsep dan Standar Laporan Keuangan Eksternal. 1977. Pernyataan tentang Teori Akuntansi dan Teori Penerimaan. Sarasota, FL: AAA.

b) Demski, J. S., dan D. E. M. Sappington. 1989. Struktur hirarkis dan akuntansi pertanggungjawaban, Jurnal Akuntansi Penelitian 27 (Spring): 40-58.

c) Dye, R. B., dan R. Magee. 1989. Biaya Kontijensi untuk perusahaan audit. Kertas kerja, Northwestern University, Evansto, IL.

d) Indriantoro, N. 1993. Pengaruh Penganggaran Partisipatif Terhadap Prestasi Kerja dan Kepuasan Kerja dengan Locus of Control dan Dimensi Budaya sebagai Moderating Variabel. Ph.D. Disertasi. University of Kentucky, Lexington.

e) Naim, A. 1997. Analisis Penggunaan Akuntansi Biaya Produk Dalam Keputusan Harga oligopolistik. Jurnal Ekonomi Dan Bisnis Indonesia 12 (3): 43-50.

f) Porcano, T. M. 1984a. Keadilan distributif dan Kebijakan Pajak. Akuntansi Ulasan 59 (4): 619-636.

g) -------. 1984b. Pengaruh Persepsi Kebijakan Pajak Niat Investasi Perusahaan. The Journal of American Association Perpajakan 6 (Fall): 719.

h) Pyndyk, R. S. dan D. L. Rubinfield. 1987. Model ekonometrik \& Forecasts Ekonomi, 3rd ed. NY: McGraw-Hill Publishing, Inc.

12. Author(s) harus melampirkan CV, alamat email, alamat korespondensi dan pernyataan yang menyatakan pasal tersebut tidak sedang disampaikan kepada atau diterbitkan oleh jurnal lain dalam email tersebut dan /atau pos. 


\title{
PENGARUH TINGKAT SUKU BUNGA SIMPANAN TERHADAP JUMLAH DEPOSITO PADA PT. BANK RAKYAT INDONESIA (PERSERO) TBK. CABANG LIWA
}

\author{
Indrayenti \\ Susanti \\ (Universitas Bandar Lampung) \\ email: indrayenti@ubl.ac.id \\ email: Suzan_48@ymail.co.id
}

\begin{abstract}
Penelitian ini menjelaskan tentang pengaruh tingkat suku bunga simpanan terhadap jumlah deposito pada PT. Bank Rakyat Indonesia (persero) Tbk. Cabang Liwa. Penelitian bertujuan untuk mengetahui apakah ada pengaruh tingkat suku bunga simpanan terhadap jumlah deposito pada PT. Bank Rakyat Indonesia (persero) Tbk. Cabang Liwa. Dalam penelitian ini sampel yang diambil adalah data penerimaan dana deposito pada tahun 2012. Penelitian ini menggunakan metode pengumpulan data melalui metode kepustakaan dan pengumpulan data melalui studi lapangan. Teknik analisis yang digunakan adalah regresi linier sederhana dengan menggunakan program SPSS 17,0. Dengan demikian, berdasarkan hasil penelitian dapat disimpulkan bahwa nasabah lebih dominan memilih suku bunga yang berjangka 1 bulan. Tingkat suku bunga simpanan antara jangka 1 bulan, 3 bulan, 6 bulan,dan 12 bulan terdapat selisih yang sangat rendah. . Tidak terdapat pengaruh yang signifikan antara tingkat suku bunga simpanan terhadap jumlah deposito pada PT. Bank Rakyat Indonesia (persero) Tbk. Cabang Liwa diterima, karena dilihat pada laporan tingkat suku bunga deposito nasabah lebih dominan memilih tingkat suku bunga yang lebih rendah dan sebaliknya pada tingkat suku bunga yang lebih tinggi Bank Rakyat Indonesia Cabang Liwa menghimpun dana yang lebih sedikit. Hal ini menunjukkan bahwa jumlah deposito tidak hanya dipengaruhi oleh tingkat suku bunga tetapi deposito dapat juga dipengaruhi oleh jangka waktu. Berdasarkan kesimpulan maka penulis menyarankan agar Bank Rakyat Indonesia menawarkan tingkat suku bunga yang jauh lebih tinggi untuk deposito yang berjangka lebih lama.
\end{abstract}

Keywords: Suku Bunga, Simpanan, Deposito

\section{Latar Belakang}

Dunia perbankan sebagai lembaga keuangan dan peraturan akan selalu bersaing untuk mendapatkan kepercayaan dari masyarakat dan pengusaha pemilik modal untuk menyalurkan dananya kepada pihak yang memerlukan. Oleh karena itu pemerintah selalu berusaha untuk menghidupkan dan memperbaiki dunia perbankan melalui berbagai paket kebijaksanaan yang berupa paket deregulasi, khususnya yang berkenaan dengan sektor perbankan. Pada dasarnya inti dari semua kebijaksanaan yang ada adalah untuk memberikan kebebasan kepada dunia perbankan dalam usahanya menghimpun dana dari masyarakat dan kemudian menyalurkannya kembali kepada masyarakat. 
Dalam liberalisasi perbankan telah mencapai beberapa sasaran baik dalam menghimpun sumber-sumber dana, peningkatan efisiensi kerja perbankan maupun dalam peningkatan mekanisme pasar uang yang lebih baik. Penghimpunan dana perbankan yang terdiri dari giro, deposito dan tabungan selama periode akhir tahun mengalami peningkatan. Di tengah pesatnya perkembangan penghimpunan dana dan penyalurannya kredit perbankan pemerintah mengeluarkan kebijaksanaan baru, yang bertujuan untuk melengkapi dan menyempurnakan perkembangan sektor perbankan. Kebijaksanaan suku bunga yang realitas akan terus dikembangkan dan ini tentunya akan mempengaruhi tinggi rendahnya suku bunga yang ditetapkan sedemikian rupa yang tidak memberatkan bagi usaha pembangunan dan juga tidak memberatkan para nasabah atau para pengusaha.

Perbankan merupakan salah satu tempat popular menurut UU RI No 10 Tahun 1988 tanggal 10 November 1988 tentang perbankan, dapat disimpulkan bahwa usaha perbankan meliputi tiga kegiatan, yaitu menghimpun dana, menyalurkan dana, dan memberikan jasa bank lainnya. Kegiatan menghimpun dan menyalurkan dana merupakan kegiatan pokok bank sedangkan memberikan jasa bank lainnya hanya kegiatan pendukung. Kegiatan penghimpun dana, berupa mengumpulkan dana dari masyarakat dalam bentuk simpanan giro, tabungan, dan deposito.

Bank merupakan sarana yang memudahkan aktivitas masyarakat untuk menyimpan uang, dalam hal perniagaan maupun untuk investasi masa depan. Dunia perbankan merupakan salah satu institusi yang sangat berperan dalam bidang perekonomian suatu Negara (khususnya dibidang pembiayaan perekonomian). Manfaat perbankan dalam kehidupan sebagai modal investasi, yang berarti, transaksi derivative dapat dijadikan sebagai salah satu modal berinvestasi. Dalam memasarkan deposito PT. Bank Rakyat Indonesia (persero) Tbk. Cabang Liwa memberikan pelayanan yang baik serta rasa aman dalam mengenvestasikan uangnya. Salah satunya dengan menawarkan produk deposito dengan tingkat suku bunga sebagai berikut:

Periode 1 bulan bunga depositonya 4,25\% dengan jumlah deposito Rp 4.273.925.192, periode 3 bulan bunga depositonya 4,75\% dengan jumlah deposito Rp 112.000.000, periode 6 bulan bunga depositonya 5,00\% dengan jumlah deposito Rp 266.000.000, periode 12 bulan bunga depositonya 5,25\% dengan jumlah deposito Rp 200.000.000. 


\section{Telaah Literatur dan Pengembangan Hipotesis}

\subsection{Teori yang mendasari}

Berdasarkan Undang-Undang Nomor 10 Tahun 1998 tentang perubahan atas undangundang Nomor 7 tahun 1992 tentang perbankan, yang dimaksud dengan bank adalah badan usaha yang menghimpun dana dari masyarakat dalam bentuk kredit dan atau bentuk-bentuk lainnya dalam rangka meningkatkan taraf hidup rakyat banyak. Menurut Kasmir (2012:3), bank adalah lembaga keuangan yang kegiatan usahanya adalah menghimpun dana dari masyarakat dan menyalurkan kembali dana tersebut kemasyarakat serta memberikan jasa-jasa bank lainnya.

Pengertian suku bunga adalah harga dari pinjaman. Suku bunga dinyatakan sebagai persentase uang pokok perunit waktu. Bunga merupakan suatu ukuran harga sumber daya yang digunakan oleh debitur yang harus dibayarkan kepada kreditur. Kasmir (2012), mengungkapkan bahwa bunga bank dapat diartikan sebagai balas jasa yang diberikan oleh bank yang berdasarkan prinsip konvensional pada nasabah yang membeli atau menjual produknya. Bunga dapat juga sebagai harga yang harus dibayar kepada nasabah (yang memiliki simpanan) dengan yang harus dibayar oleh nasabah (yang memperoleh pinjaman) kepada bank. Menurut Kasmir (2012:154), ada dua macam bunga yang diberikan kepada nasabahnya, yaitu:

1. Bunga simpanan

Merupakan harga beli yang harus dibayar bank kepada nasabah pemilik simpanan. Bunga ini diberikan sebagai rangsangan atau balas jasa, kepada nasabah yang menyimpan uangnya di bank. Sebagai contoh jasa giro, bunga tabungan, dan bunga deposito.

2. Bunga pinjaman

Merupakan bunga yang dibebankan kepada peminjam (debitur) atau harga jual yang harus dibayar oleh nasabah peminjam kepada bank. Bagi bank bunga pinjaman merupakan harga jual dan contoh harga jual adalah bunga kredit.

Menurut Miller, dkk (2004), tingkat suku bunga adalah harga dari penggunaan uang untuk jangka waktu tertentu atau harga dari penggunaan uang yang dipergunakan dan akan dikembalikan pada saat mendatang. Menurut Undang-Undang RI No.10 tahun 1998 tentang Perbankan Bab I Pasal 1 ayat 7, yang dimaksud dengan deposito adalah “ simpanan yang penarikannya hanya dapat dilakukan pada waktu tertentu berdasarkan perjanjian nasabah penyimpanan dengan bank". Juddiseno (2004), mengemukakan bahwa deposito adalah 
sejenis simpanan yang penarikannnya hanya dapat dilakukan setelah jangka waktu tertentu sesuai dengan perjanjian antara nasabah penyimpan (deposan) dengan bank. Jenis deposito yang ditawarkan oleh bank dan ada dimasyarakat adalah sebagai berikut:

a) Deposito berjangka adalah deposito yang diterbitkan menurut jangka waktu tertentu. Jangka waktu deposito biasanya bervariasi mulai dari 1, 2, 3, 6, 12, 18, sampai dengan 24 bulan. Deposito berjangka diterbitkan atas nama baik perorang maupun lembaga. Artinya didalam bilyet deposito tercantum nama seseorang atau lembaga.

b) Sertifikat deposito adalah deposito yang diterbitkan dengan jangka waktu 2, 3, 6, dan 12 bulan. Sertifikat deposito diterbitkan atas unjuk dalam bentuk sertifikat. Artinya didalam sertifikat deposito tidak tertulis nama seseorang atau badan hukum tertentu. Disamping itu serfikat deposito dapat diperjual belikan pada pihak lain.

c) Deposit on call adalah deposito yang berjangka waktu minimal 7 hari dan paling lama kurang dari 1 bulan. Diterbitkan atas nama dan biasanya dalam jumlah yang besar misalnya 50 juta rupiah (tergantung bank yang bersangkutan).

Bunga deposito dihitung mulai dari penyetoran dana sampai dengan hari pengambilan kembali atau yang disebut dengan jatuh tempo. Perhitungan tiap bulan sesuai dengan jumlah hari sebenarnya dari bulan yang bersangkutan, dan jumlah hari bunga dalam satu tahun dihitung sebanyak 365 hari. Dengan demikian perhitungan besarnya bunga deposito yang diterima deposan adalah sebagai berikut:

Bunga deposito $=$ Nominal deposito $\mathrm{x}$ Suku bunga $\mathrm{x}$ Hari (365)

Penarikan bunga dapat dilakukan dengan cara bermacam-macam sesuai dengan perjanjian sewaktu pembukaan rekening, yaitu:

a. Dapat ditarik tunai setiap bulan

b. Dapat ditarik setelah deposito jatuh tempo

c. Dapat ditambahkan kenominal deposito setelah jatuh tempo jangka waktunya

d. Dapat dipindah bukukan kerekening tabungan atau rekening giro

e. Dapat dipindah bukukan kerekening pemilik di bank lain.

\subsection{Penelitian terdahulu dan Hipotesis}

Penelitian Restyono (2011), tentang pengaruh tingkat suku bunga deposito terhadap jumlah dana deposito berjangka pada PT. Bank SulSelBar cabang utama Makassar terdapat hubungan yang kuat antara tingkat suku bunga terhadap dana deposito. Besar kecilnya tingkat suku bunga deposito mempengaruhi jumlah deposito berjangka pada PT. Bank SulSelBar 
cabang utama Makassar. Penelitian Bara'padang (2008), tentang Analisis pengaruh tingkat suku bunga deposito terhadap jumlah deposito pada PT. Bank Niaga Tbk. Makassar terdapat pengaruh yang signifikan. Besar kecilnya tingkat suku bunga deposito sangat mempengaruhi jumlah deposito dari PT. Bank Niaga Tbk Makassar.

\section{Metodologi Penelitian}

\subsection{Pemilihan Sampel}

Sampel didefinisikan sebagai bagian dari populasi. Populasi dalam penelitian ini adalah semua deposan baik perorangan ataupun lembaga baik keuangan lainnya dan terbagi menjadi deposan primer maupun sekunder. Setiap terjadi perubahan tingkat suku bunga pihak bank akan menginformasikan terlebih dahulu ke deposan dengan memperhatikan etika kerahasiaan bank. Untuk mengambil sampel dalam penelitian ini, penulis menggunakan teknik pengambilan sampel yaitu, sampel data untuk 1 tahun yaitu tahun 2012 yang mewakili populasi didalam penelitian ini.

\subsection{Data}

Jenis data penelitian ini adalah data kuantitatif, berupa laporan keuangan PT. Bank Rakyat Indonesia (persero) Tbk. Cabang Liwa selama setahun, yaitu laporan tingkat suku bunga deposito PT. Bank Rakyat Indonesia (persero) Tbk. Cabang Liwa, dan data Kualitatif, berupa sejarah singkat perusahaan, dan struktur organisasi perusahaan. Selain jenis data, dalam penelitian ini juga digunakan sumber data yaitu Data Sekunder. Data yang diperoleh adalah dokumen perusahaan yaitu berupa laporan tingkat suku bunga deposito PT. Bank Rakyat Indonesia (persero) tbk. Cabang Liwa tahun 2012. Untuk memperoleh data yang dibutuhkan dalam menunjang pembahasan penulisan skripsi ini, maka penulis menggunakan prosedur pengumpulan data sebagai berikut :

1. Penelitian lapangan (field research) yaitu penelitian secara langsung ke PT. Bank Rakyat Indonesia (persero) Tbk. Cabang Liwa yang bertujuan untuk memperoleh data yang dibutuhkan sehubungan dengan tingkat suku bunga simpanan dan jumlah deposito.

2. Wawancara (Interview) yaitu dengan melakukan wawancara terhadap funding officer.

3. Penelitian kepustakaan (library research) yaitu penelitian yang bertujuan untuk memperoleh konsep dan landasan teori dengan mempelajari berbagai literatur, buku, 
referensi, dan dokumen-dokumen yang berkaitan dengan tingkat suku bunga simpanan dan deposito.

\subsection{Model Penelitian dan Pengujian Statistika}

Metode yang digunakan untuk memecahkan masalah yang akan diteliti yaitu melalui analisis regresi sederhana dan pengujian hipotesis. Menurut Sanusi (2013:132), rumus regresi sederhana, yaitu :

$\mathrm{Y}=\mathrm{a}+\mathrm{bX}$

$\mathrm{b}=\underline{\mathrm{n} \Sigma \mathrm{XY}-\Sigma \mathrm{X} \Sigma \mathrm{Y}}$

$\mathrm{n} \Sigma \mathrm{X}^{2}-(\Sigma \mathrm{X})^{2}$

$\mathrm{a}=\underline{\Sigma \mathrm{Y}-\mathrm{b} \Sigma \mathrm{Y}}$

keterangan :

Y : Jumlah deposito, diukur dengan besarnya nilai mata uang pada PT. Bank Rakyat indonesia cabang Liwa, variabel terikat (dependen).

$\mathrm{X}$ : Tingkat suku bunga diukur dengan persen (\%) yang merupakan variabel bebas (independen).

$\mathrm{n}$ : Jumlah data yang dianalisis.

a : Jumlah pasang observasi $=$ nilai konstan.

b : Koefisien regresi.

\section{Pengujian Hipotesis}

a. Uji koefisien determinasi $\left(\mathrm{R}^{2}\right)$

b. Uji parsial (uji t)

\subsection{Definisi Operasional Variabel Penelitian}

1. Suku bunga, diartikan sebagai balas jasa yang diberikan oleh bank yang berdasarkan prinsip konvensional kepada nasabah yang membeli atau menjual produknya.

2. Deposito, merupakan salah satu faktor yang cukup besar pengaruhnya terhadap aktivitas perbankan dan merupakan salah satu sumber dana pembiayaan, operasionalnya yang disalurkan lewat kredit untuk membantu permodalan para pengusaha yang melakukan investasi. 


\section{Hasil dan Pembahasan}

\subsection{Data Penelitian}

Tabel 1

Tingkat Suku Bunga Deposito

PT. Bank Rakyat Indonesia (persero) Tbk. Cabang Liwa Tahun 2012

\begin{tabular}{|c|c|c|}
\hline Periode & $\begin{array}{c}\text { Tingkat suku bunga deposito(\%) } \\
(\mathrm{X})\end{array}$ & $\begin{array}{c}\text { Jumlah Deposito (Rp) } \\
(\mathrm{Y})\end{array}$ \\
\hline $1 \mathrm{~B} \ln$ & 4,25 & 4.273 .925 .192 \\
\hline $3 \mathrm{~B} \ln$ & 4,75 & 112.000 .000 \\
\hline $6 \mathrm{~B} \ln$ & 5,00 & 266.000 .000 \\
\hline $12 \mathrm{~B} \ln$ & 5,25 & 200.000 .000 \\
\hline
\end{tabular}

Berdasarkan tabel diatas tingkat suku bunga tidak mempengaruhi jumlah deposito. Dari tabel diatas juga dapat dilihat bahwa tingkat suku bunga yang rendah dapat menghimpun dana deposito lebih tinggi. Periode 1 bulan bunga depositonya 4,25\% dengan jumlah deposito Rp 4.273.925.192, periode 3 bulan bunga depositonya 4,75\% dengan jumlah deposito $\mathrm{Rp}$ 112.000.000, periode 6 bulan bunga depositonya 5,00\% dengan jumlah deposito $\mathrm{Rp}$ 266.000.000, periode 12 bulan bunga depositonya 5,25\% dengan jumlah deposito $\mathrm{Rp}$ 200.000 .000 .

\subsection{Analisis Regresi Sederhana}

Setelah dilakukan pengujian dengan menggunakan program komputer SPSS 17.0 hasil dari data diatas adalah sebagai berikut:

\section{Tabel 2}

Hasil perhitungan regresi sederhana

\begin{tabular}{|l|l|r|r|}
\hline \multicolumn{2}{|l|}{ Model } & \multicolumn{2}{|c|}{ Unstandardized Coefficients } \\
\cline { 3 - 4 } \multicolumn{2}{l|}{} & B & Std. Error \\
\hline 1 & (Constant) & 34,173 & 8,000 \\
\cline { 2 - 4 } & TINGKAT SUKU BUNGA & $-2,985$ & 1,657 \\
\hline
\end{tabular}

Sumber : hasil olahan SPSS

$$
\begin{aligned}
& a=34,173 \\
& b=-2,985
\end{aligned}
$$

Hasil penelitian diperoleh model persamaan regresi sederhana dimana $\mathrm{Y}=\mathrm{a}+\mathrm{bx}$. Berdasarkan hasil perhitungan maka persamaannya adalah sebagai berikut : $\mathrm{Y}=34,173+(2,985 \mathrm{x})$ dimana $\mathrm{a}=\mathrm{Rp} 34,173$ milyar, artinya jika tidak ada penambahan tingkat suku bunga simpanan maka jumlah deposito adalah sebesar Rp 34,173 milyar. $b=-2,985$ menyatakan bahwa setiap penurunan tingkat suku bunga 1\% maka jumlah deposito PT. Bank Rakyat Indonesia (persero) Tbk. Cabang Liwa akan mengalami peningkatan sebesar 2,985\%. 


\subsection{Pengujian Hipotesis, Hasil dan Diskusi}

Untuk membuktikan secara parsial apakah terdapat pengaruh antara tingkat suku bunga simpanan terhadap jumlah deposito pada PT. Bank Rakyat Indonesia (persero) Tbk. Cabang Liwa, maka dapat dilakukan Uji-t sebagai berikut:

a. $\quad \mathrm{T}_{\text {hitung }}<\mathrm{T}$ tabel : Maka Ho diterima (tidak ada pengaruh antara tingkat suku bunga simpanan terhadap jumlah deposito)

b. $\quad \mathrm{T}_{\text {hitung }}>\mathrm{T}$ tabel : maka Ho ditolak (Ada pengaruh antara tingkat suku bunga simpanan terhadap jumah deposito)

$\mathrm{Df}=2$

Standar eror $\alpha=0,05$

1. $\mathrm{T}_{\text {hitung }}=-1,801$ (lampiran 3 )

2. $\mathrm{T}_{\text {tabel }}=2,920$ (tabel distribusi $\mathrm{t}$ )

Tabel 3

Tabel distribusi t

\begin{tabular}{|c|c|c|c|c|}
\hline $\mathrm{df}$ & 0,10 & 0,05 & 0,025 & 0,01 \\
\hline 1 & 3,078 & 6,314 & 12,706 & 31,821 \\
2 & 1,886 & 2,920 & 4,303 & 6,965 \\
3 & 1,638 & 2,353 & 3,182 & 4,541 \\
4 & 1,533 & 2,132 & 2,776 & 3,747 \\
5 & 1,476 & 2,015 & 2,571 & 3,365 \\
\hline
\end{tabular}

Karena $\mathrm{T}_{\text {hitung }}-1,801<\mathrm{T}_{\text {tabel }} 2,920$ maka dapat dikatakan bahwa secara parsial tidak terdapat pengaruh yang signifikan antara tingkat suku bunga simpanan terhadap jumlah deposito pada PT. Bank Rakyat Indonesia (persero) Tbk. Cabang Liwa.

Dari hasil analisis regresi sederhana dapat dilihat bahwa tingkat suku bunga tidak mempengaruhi jumlah deposito. Tabel dibawah ini juga akan menjelaskan hubungan variabel.

Tabel 4

Hasil analisis regresi sederhana

\begin{tabular}{|l|r|r|r|}
\hline Model & \multicolumn{1}{|c|}{ R } & R Square & $\begin{array}{c}\text { Adjusted R } \\
\text { Square }\end{array}$ \\
\hline 1 & $.787^{\mathrm{a}}$ &, 619 &, 428 \\
\hline
\end{tabular}

Sumber : hasil olahan SPSS

Koefisien korelasi dalam penelitian ini adalah sebesar 0,787 yang artinya tingkat suku bunga simpanan memiliki korelasi terhadap jumlah deposito sebesar 78,7 \%. Berdasarkan tabel hasil analisis korelasi menunjukkan bahwa koefisiensi determinasi adjusted $\left(\mathrm{R}^{2}\right)$ yang 
digunakan untuk mengetahui besarnya pengaruh tingkat suku bunga terhadap jumlah deposito adalah sebesar 0,428 yang berarti pengaruh tingkat suku bunga simpanan terhadap jumlah deposito adalah sebesar $42,8 \%$ dan besar nya variabel lain yang memengaruhi jumlah deposito adalah sebesar $57,2 \%$.

\section{Simpulan dan Saran}

\subsection{Simpulan}

Berdasarkan uraian-uraian yang telah dipaparkan oleh peneliti mengenai pengaruh tingkat suku bunga simpanan terhadap jumlah deposito pada PT. Bank Rakyat Indonesia (persero) Tbk. Cabang Liwa dengan data yang telah dikumpulkan dan diolah, maka peneliti dapat mengambil kesimpulan sebagai jawaban atas pertanyaan yang terdapat pada perumusan masalah yang menjadi dasar maksud dan tujuan penelitian adalah sebagai berikut:

1. Tingkat suku bunga simpanan antara jangka 1 bulan, 3 bulan, 6 bulan,dan 12 bulan terdapat selisih yang sangat rendah, sehingga nasabah lebih dominan memilih suku bunga yang berjangka 1 bulan

2. Tingkat suku bunga simpanan terhadap jumlah deposito pada PT. Bank Rakyat Indonesia (persero) Tbk. Cabang Liwa tidak terdapat pengaruh yang signifikan

\subsection{Saran}

Berdasarkan penelitian yang telah dilakukan maka peneliti dapat memberikan saran sebagai berikut:

1) Bank Rakyat Indonesia disarankan untuk menawarkan tingkat suku bunga simpanan yang jauh lebih tinggi untuk deposito yang berjangka lebih lama agar dapat meningkatkan jumlah nasabah pada tabungan deposito yang berjangka lebih lama sehingga tingkat suku bunga simpanan berpengaruh terhadap jumlah deposito.

2) Perusahaan disarankan untuk melakukan observasi keinginan nasabah agar mereka ingin mendepositokan dananya pada Bank Rakyat Indonesia.

3) Disarankan bagi penelitian selanjutnya untuk mengambil sampel penelitian yang ruang lingkupnya lebih luas agar hasil penelitian dapat sesuai dengan teori bahwa tinggi rendah nya tingkat suku bunga sangat mempengaruhi jumlah deposito. 


\section{Daftar Pustaka}

Ardiyos. 2008. Kamus Besar Akuntansi. Jakarta: Citra Harta Prima.

Bara'padang, Melky. 2008. Analisis Pengaruh Tingkat suku bunga Deposito Terhadap Jumlah Deposito Pada PT. Bank Niaga Tbk Makasar. Skripsi. Universitas Hassanuddin Makassar.

Dendawijaya, Lukman. 2005. Manajemen Perbankan. Bogor : Ghalia Indonesia.

Iskandar, Syamsu. 2013. Bank dan Lembaga Keuangan Lainnya. Jakarta : IN media.

Ismail. 2010. Akuntansi Bank. Surabaya : kencana, prenada media group.

Juddiseno, Rimsky. 2004. Perpajakan. Jakarta: Edisi Revisi, Gramedia Pustaka Utama.

Kamus Besar Bahasa Indonesia. 2008. Jakarta: Edisi keempat, Gramedia Pustaka Utama.

Kasmir. 2012. Dasar-dasar Perbankan. Jakarta : Rajawali Pers. 102-158.

Miller, RL dan Vanhoose, Sawaldjo, Puspopranoto. 2004. Keuangan Perbankan dan Pasar Keuangan. Jakarta : LP3ES Indonesia

Pohan, Aulia. 2008. Kerangka Kebijakan Moneter dan Implikasinya di Indonesia. Jakarta: Grafindo Persada.

Restyono, Ahmad Bagas. 2011. Pengaruh Tingkat Suku Bunga Deposito Terhadap Jumlah Dana Deposito Berjangka Pada PT. Bank SulSelBar Cabang Utama Makassar. Skripsi. Universitas Hassanuddin Makassar.

Sanusi, Anwar. 2013. Metodologi Penelitian Bisnis. Jakarta: Salemba Empat.

$$
\text { 122-132. }
$$

Sunariyah. 2004. Pengantar Pasar Modal. Yogyakarta: Edisi keempat, UPP AMP YPKN.

Tandeliin, Eduardus. 2001. Analisis Investasi dan Manajemen dan Portofolio. Yogyakarta: Edisi Pertama Cetakan Pertama, BPFE.

Taswan. 2010. Manajemen Perbankan. Yogyakarta : UPP STIM YKPN.

Undang-Undang. Nomor 10 Tahun 1998 tentang Perubahan Atas Undang-Undang Nomor 7 Tahun 1992 tentang Perbankan. Pasal 1 Ayat (2). 